\title{
INNOVATIVE CLASSIFICATION OF METHODS OF THE FUTURE-ORIENTED TECHNOLOGY ANALYSIS
}

\author{
Katarzyna HALICKA \\ Bialystok University of Technology, Wiejska 45A str., 15-351 Bialystok, Poland
}

Received 23 October 2015; accepted 28 February 2016

\begin{abstract}
In the era characterized by significant dynamics of the environment traditional methods of anticipating the future, assuming the immutability of the factors affecting the forecasted phenomenon, may be in the long term ineffective. The modern approach of predicting the future of technology, taking into account the multidimensionality of the environment, is, among other things, the Future-Oriented Technology Analysis (FTA). Designing the FTA research procedure is a complex process, both in organizational and methodological terms. The catalogue of methods that can be used in this process is extensive and constantly open. However, in the source literature the rules for the selection of methods appropriate for the type of research were not specified. The ways of combining methods in the research process were also missing. The main aim of this article was to present the author's classification of methods of future-oriented technology analysis and indicate the possibilities of its application. In the text, using statistical methods and artificial neural networks, the classification of methods with the potential of exploitation in prospective technology analysis was carried out. Each of the received classes was analysed, the characteristics of particular groups of methods were selected, and authorial names characterizing the given classes were chosen. According to the author, the application of the proposed classification of methods of future-oriented technology analysis facilitates the design of the FTA research process. It will contribute to the systematization and standardization of the manner of selection of research methods. It will also allow for the selection of complementary methods.
\end{abstract}

Keywords: technology analysis, technology foresight, technology assessment, technology forecasting, classification, Future-oriented Technology Analysis, artificial neural networks.

JEL Classification: C38, C45, C44, O31, O32, O33, E27.

\section{Introduction}

The dynamic development of the industry, in the conditions of globalization and strong competition, determines the use of new, innovative, more efficient and economically viable technologies. One of the important factors giving evidence of the competitive businesses

Corresponding author Katarzyna Halicka

E-mail: k.halicka@pb.edu.pl 
are the technical and technological resources owned by them, including knowledge and innovation. In the situation of the increasing demand for innovative technologies and a broad technology trading market, the issue of in-depth analysis of technology is gaining in importance. It is an essential element of technology management and is used, inter alia, in: (i) the exploitation of technology owned by the company; (ii) the acquisition of new technologies that would improve the competitiveness of the enterprise or prevent its deterioration; (iii) exchange of the already applied technology and introduction of new technologies in its place.

An in-depth analysis of the technology is difficult, because of the costs, the complexity of the problem and above all the pace of technological change on the global market. The analysis of technology requires the possession of appropriate resources of knowledge that is dispersed, and also concerns many aspects of technological development. During the analysis of technology the tools and skills allowing for carrying out the substantive assessment of the technical characteristics and the properties of technologies are useful. The knowledge about current trends in technology is also necessary. According to the current trends, technology analysis should take into account the economic, technical, social, as well as environmental factors. It is therefore necessary to use specific systems and tools, thanks to which the investment in research and development, the infrastructure and the qualifications of the staff will be tailored to the current, as well as future market and industrial needs (Ejdys et al. 2015). Those prerequisites justify the use of appropriate - future-oriented - methods of technology analysis. The Future-oriented Technology Analysis approach belongs to such tools. The FTA enables the investigation of the interaction of technology with the environment and the identification of factors affecting the development of the technology, but also the indication of the effects of the impact of technology on the environment. It supports the determination of directions of a given technology development in the long term perspective. It also enables the specification of the level of maturity of a given technology and the identification of obsolete technologies. It facilitates the identification of emerging new technologies.

The FTA term was first used in 2004 in the title of a seminar on New Horizons and Challenges for Future-Oriented Technology Analysis: New Technology Foresight, Forecasting and Assessment organized by the Institute for Prospective Technological Studies (IPTS). Then, the FTA concept was defined as the so-called "umbrella" that covered a number of different methods of technology analysis in the field of technology foresight, technology forecasting and technology assessment (Cagnin et al. 2008). According to Saritas et al. (2014) FTA explains a broad range of future-looking activities involving foresight, forecasting, futures, and technology assessment among the others. However, in the opinion of Boden, Johnston, Scapolo (2012) FTA facilitates decision-making and coordination of future activities, especially in the fields of science, technology and innovation as well as politics. On the other hand, some researchers such as H. Haegeman, F. Scapolo and C. Cagnin, A. Havas and O. Saritas claimed that the future-oriented technology is a common term denominating a collection of different tools that can be used to study and understand the future of technologies from different methodological perspectives (Haegeman et al. 2013; Cagnin et al. 2013). Over time, FTA started to be treated as a kind of future management concept. 
This approach began to develop in two parallel trends: technological and decision-making. In the first, methods and tools necessary to analyse, assess, predict the development of technologies (Huang et al. 2012b) as well as manage their future were used (Cheng et al. 2008). In the second, FTA began to be treated as a tool for policy-making, a tool used by policymakers (Cagnin et al. 2011; Carabias-Huetter, Haegeman 2013; Georghiou, Harper 2013; Kim et al. 2010; Kwakkel, Pruyt 2013; Marinho, Cagnin 2014; Weber et al. 2012). The research conducted by the author is located in the first mainstream, the technology mainstream. When reviewing the database of scientific IEEE publications and Web of Science, as well as websites it can be noted that FTA is most commonly used to analyse emerging technologies (Robinson, Propp 2008) specifically related to such areas as: nanotechnology (Alencar et al. 2007; Ma et al. 2014; Huang et al. 2011; Schaper-Rinkel 2013), micro and nanoelectronics (Gesche et al. 2012; Huang et al. 2012a; Markus, Mentzer 2014; Moore et al. 2014; Robinson et al. 2013) and renewable energy sources (Guo et al. 2012, 2011; Halicka 2011; Halicka et al. 2015; Nygren et al. 2015).

The abovementioned definitions - regardless of the study trend - are generic and do not reflect the nature of the FTA approach. Therefore, the author proposes her own definition of FTA as a process, the main objective of which is to predict the future of technology through evaluation and detailed analysis (scanning) of its current state and identification of strategic factors of its development in the future. Designing the process of future-oriented technology analysis is a difficult, multi-stage project, providing various relevant information on the analysed technologies at every stage. This information may relate to the technology itself, but also to the factors affecting a particular technology and its development. They may determine both the impact of the environment on technology and technology on the environment. They can also be considered in different time perspectives, i.e. may relate to the past, present and future of the technology. According to the author, the FTA process is carried out through the following functions:

1. Collecting information on the purpose and scope of technology analysis.

2. Collecting and organizing information on technology.

3. Processing information associated with the current development of technology.

4. Processing and generating new information on the current state of technology.

5. Collecting information on the impact of the environment on technology and technology on the environment.

6. Transmission of the acquired information on technology.

7. Collecting information on the factors affecting the development of technology.

8. Generating new information concerning the development of the technology.

9. Interpreting and using the obtained information.

Due to diverse functions implemented during the future-oriented technology analysis, there is no single best method with the use of which a research problem can be solved. It is necessary to use several different methods. However, a set of methods that can be used in FTA is comprehensive (Amanatidou et al. 2009; Georghiou et al. 2011; Loveridge, Saritas 2012). These methods may be used in different ways, depending on the features and context of the analyses (Halicka 2015; Hamarat et al. 2013; Shin et al. 2013). Some of these 
methods are similar to each other and can be used interchangebly (Damrongchai et al. 2010). However, the source literature presents neither the principles of selection of appropriate research methods, nor the ways to combine them. It is, therefore, important to collect, analyse and classify the methods with the potential of use in the FTA. Classes obtained in such a manner - integrating research methods possible to use in a prospective analysis of technology - will help to facilitate and standardize the whole process of designing FTA.

The above-mentioned proposals for the design of the FTA process justify the purposefulness of undertaking a research task, which consists, inter alia, in the development of methodology for classification of methods of future-oriented technology analysis.

\section{The current classification of methods used in FTA - a literature review}

FTA is a process that uses a variety of methods allowing for a detailed characterization and systematic analysis of technology as well as identification and presentation of its development paths. According to Marinelli et al. (2014) the future-oriented technology analysis is particularly useful when technologies are costly but essential for the development of a country, region or company. This approach combines forecasting technology (TF) technology assessment (TA) and technology foresight.

Technological forecasting is a kind of technology development prediction, allowing for studying the changes in technology, presenting its development path or functional capabilities (Ayres 1969; Nazarko 1993). Technological forecasting is primarily based on data from the past and generally refers to the near future (time horizon - up to several years) (Cuhls 2003; Cunningham, Kwakkel 2011; Makridakis, Wheelwright 1978; Nazarko 2011). On the other hand, to standardize the definitions available in the literature, technology assessment can be defined as the measurement of specific technologies and their consequences from the point of view of the social, economic and environmental criteria (De Piante Henriksen 1997; Mazurkiewicz et al. 2015; Musango 2012). According to A. E. Gudanowska (2013, 2014a) it is an assessment and analysis of the impact of the existing technologies on the society. However, in the opinion of B. Martin (2001) and J. Nazarko (Nazarko et al. 2011, 2012; Nazarko 2013) technological foresight is aimed at activities enabling the creation of the future, allows to predict both future characteristics of new technologies and the period of their appearance. Technology assessment, forecasting its development and foresight studies form the basis of FTA; hence, these approaches show great consistency in terms of methodology. However, taking into account the studies conducted by Andersen, Alkærsig (2014) and Mikova, Sokolova (2014), these approaches are not the same. Each of these projects plays completely separate role and very often they complement one another.

Methods used in the future-oriented technology analysis are derived from both the social sciences (Eerola, Miles 2011), as well as technical sciences (Halicka 2014; Idier 2000). They are often modified for the purpose of far-reaching analyses of technology development. A set of methods that can be used in FTA is open (May 1996). Selection of appropriate methods for the future-oriented technology analysis - with such a vast catalogue - especially for a novice researcher, can be a big challenge. Organising and classifying methods with similar properties into classes seems helpful. Initially, the author has reviewed the 
existing classification of the research methods of future. Table 1 presents a summary of selected classifications of methods used in all areas of FTA.

When analysing Table 1 in detail, it can be noticed that classifications available in the literature order the methods only in terms of methods' nature, and do not take into account the multi-stage nature of FTA, and above all, do not take into account different - important - functions performed in the course of a future-oriented technology analysis.

Table 1. Selected examples of common classifications of research methods of future

\begin{tabular}{|c|c|c|c|}
\hline Area & $\begin{array}{l}\text { The number } \\
\text { of classes } \\
\text { and methods }\end{array}$ & $\begin{array}{l}\text { Names of classes (the number } \\
\text { of methods in each class) }\end{array}$ & $\begin{array}{l}\text { The author of the } \\
\text { classification }\end{array}$ \\
\hline forecasting & $\begin{array}{l}3 \text { classes } \\
21 \text { methods }\end{array}$ & $\begin{array}{l}\text { Correlative (5); Direct (9); } \\
\text { Structural (7) }\end{array}$ & $\begin{array}{l}\text { A. T. Roper et al. } \\
\text { (Roper et al. 2011) }\end{array}$ \\
\hline forecasting & $\begin{array}{l}5 \text { klas } \\
20 \text { methods }\end{array}$ & $\begin{array}{l}\text { Extrapolator (4); Pattern Analyst (4); } \\
\text { Goal Analyst (4); Counter-Puncher (4); } \\
\text { Intuitor (4) }\end{array}$ & J. H. Vanston (1995) \\
\hline forecasting & $\begin{array}{l}3 \text { classes } \\
31 \text { methods }\end{array}$ & $\begin{array}{l}\text { Subjective assessment methods (4); } \\
\text { Exploratory methods }(20) ; \\
\text { Normative approaches }(7)\end{array}$ & $\begin{array}{l}\text { Somnath Mishra, } \\
\text { S. G. Deshmukh, } \\
\text { Prem Vrat (Ayres } \\
\text { 1969; Makridakis, } \\
\text { Wheelwright 1978; } \\
\text { Mishra et al. 2002) }\end{array}$ \\
\hline $\begin{array}{l}\text { technology } \\
\text { assessment }\end{array}$ & $\begin{array}{l}9 \text { classes } \\
70 \text { methods }\end{array}$ & $\begin{array}{l}\text { Economic Analysis (14); Decision analysis (7); } \\
\text { Externalities/impact analysis (6); Information } \\
\text { monitoring (4); Market analysis (6); Risk } \\
\text { assessment (5); } \\
\text { Systems engineering/analysis (8); } \\
\text { Technical performance assessment (12); } \\
\text { Technology forecasting (8) }\end{array}$ & $\begin{array}{l}\text { T. A. Tran (Tran, } \\
\text { Daim 2008), De Piante } \\
\text { Henriksen (1997) }\end{array}$ \\
\hline foresight & $\begin{array}{l}4 \text { classes } \\
13 \text { methods }\end{array}$ & $\begin{array}{l}\text { Identifying Issues (3); Extrapolative } \\
\text { Approaches (4); Creative Approaches (4); } \\
\text { Prioritization (2) }\end{array}$ & $\begin{array}{l}\text { I. Miles, M. Keenan } \\
\text { (Unido 2005) }\end{array}$ \\
\hline foresight & $\begin{array}{l}3 \text { classes } \\
40 \text { methods }\end{array}$ & $\begin{array}{l}\text { Foreseeing (10); Managing (14); } \\
\text { Creating (16) }\end{array}$ & G. H. May (1996) \\
\hline foresight & $\begin{array}{l}3 \text { classes } \\
44 \text { methods }\end{array}$ & $\begin{array}{l}\text { Quantitative (11); Qualitative (22); } \\
\text { Semi-quantitative (11) }\end{array}$ & $\begin{array}{l}\text { Popper (Georghiou } \\
\text { et al. 2008) }\end{array}$ \\
\hline foresight & $\begin{array}{l}10 \text { classes } \\
117 \text { methods }\end{array}$ & $\begin{array}{l}\text { Consultative (10); Creative (12); } \\
\text { Prescriptive (15); Multicriterial (15); } \\
\text { Radar (8); Simulation (9); Diagnostic (12); } \\
\text { Analytical (17); Survey (8); Strategic (11) }\end{array}$ & A. Magruk (2011) \\
\hline FTA & $\begin{array}{l}13 \text { classes } \\
53 \text { methods }\end{array}$ & $\begin{array}{l}\text { Creativity (3); Monitoring and intelligence } \\
\text { methods (2); Descriptive (4); Matrices (3); } \\
\text { Statistical methods (2); Trend analysis (4); } \\
\text { Expert opinion (4); Modeling and simulation } \\
\text { (6); Logical/cause analysis (9); Roadmapping } \\
\text { (4); Scenarios (5); } \\
\text { Valuation (5); Modifications (2) }\end{array}$ & $\begin{array}{l}\text { A. L. Porter, F. Scapolo } \\
\text { (Cagnin et al. 2008) }\end{array}$ \\
\hline
\end{tabular}

Source: own elaboration. 
One of the first classifications of methods used for technological forecasting was proposed by A. L. Porter, T. W. Mason, F. A. Rossini, J. Banks (Roper et al. 2011). They have identified three classes: correlative, direct, and structural. Methods within the classes directly measure the functional capacity or some other relevant characteristic of the technology. In turn, correlative methods relate the development of technology to the growth or change of one or more elements in the same context or in contexts regarded as analogous. Methods belonging to structural category analyse in detail the cause-and-effect relationships that effect growth.

In contrast, Somnath Mishra, S. G. Deshmukh, Prem Vit (2002) reviewed the methods most commonly used for forecasting. They identified 31 methods and grouped them into three classes: subjective assessment methods, exploratory methods of technological forecasting, and normative approaches to technological forecasting.

One of the first classifications of methods used to foresight was developed by I. Miles and M. Keenan. They selected four classes. The first class refers to methods of scanning and defining a general framework for research. The other one includes methods using both a statistical approach (e.g. trend extrapolation), and being based on expert opinion (e.g. the Delphi method). Methods from the class three are characterized by flexibility and spontaneity in experiencing the analysed phenomena (Vanston 1995). They are used mostly to develop a vision of the studied reality. The fourth class includes methods whose purpose is to identify priorities of the development of technology.

A common classification of foresight methods is the so-called foresight diamond - the division developed by R. Popper. He distinguished three classes: quantitative, indirect and qualitative methods, considered in 4 dimensions: creativity - synergy - the facts - expertise. Creative feature is demonstrated by methods characterized by ingenuity and creative inventiveness. Expertise is an opinion, specialised examination carried out by experts. Synergy enables the creation of a common - for all participants - vision of the future. The facts are helpful in understanding the current state of the studied area of research. Qualitative methods are often based on the opinions of a particular group of people (UNIDO 2005). In turn, with the use of quantitative methods, numerical parameters characterizing the studied phenomenon or the object of study are defined. In contrast, the class of indirect methods uses both qualitative and quantitative methods. For example, the opinions of experts can be analysed using statistical models.

An interesting classification was presented by A. Magruk (2011). He identified 117 methods with the potential of use for foresight research and grouped them into 10 classes. Methods from the consultative class enable collecting and analysing opinions of a wide range of stakeholders on the study area and the factors associated with it. Class of creative methods is based on spontaneity and flexibility, it facilitates the creation of a vision of the researched items. Methods from the normative class are connected to anticipating the future, and they primarily consist in defining the vision of development. Methods of the multi-criterial class enables measuring the relationship between a group of variables and the criteria characterizing the researched items. Methods from the radar class facilitate monitoring, detecting and analysing important signals about the latest research and technological discoveries, potential innovations that could be related to the researched item. 
The class of simulation methods is made up of analytical tools, using the expertise and the characteristics of synthesis and modelling. Methods of the diagnostic class allow for an assessment of the current state of the researched object as well as management of the development of the researched object. Analytical methods refer to the study of development trends, driving forces, variants of change, the structure of the researched reality, society as well as potential stakeholders. The class of review methods allows for the diagnosis and evaluation of data relating to past operations, results and the space-time studies. Methods from the strategic class facilitate planning, scenario building, solving complex decisionmaking problems and change management (Magruk 2015).

F. Scapolo and A. L. Porter (Cagnin et al. 2008) were the first - and so far the only authors, who gathered and systematized FTA methods. They have designated 53 methods that may be used in a future-oriented technology analysis, and then classified them into 13 classes (methods families): creative approaches, monitoring \& intelligence, descriptive, matrices, statistical analyses, trend analyses, expert opinion, modelling \& simulation, logi$\mathrm{cal} /$ causal analyses, roadmapping, scenarios, valuing/decision-aiding/economic analyses, combinations.

The largest - consisting of 9 methods - is the class called logical/causal analyses. This family consists of analytical methods, determining factors affecting the economic indicator under examination and the scale of impact of individual factors on the deviation resulting from previous comparisons. Another large class is modelling and simulation. Tools from this class include primarily quantitative methods allowing for the creation of the model and identification of actions related to the creation of the future strategy of the researched subject. In contrast, the methods from the scenarios class allow for the construction of a future vision of the phenomenon, or the possible aspects of the future. In turn, the valuing/decision support/economic analysis class consists of 5 methods comprising the optimization, analysis and selection of numerous data on the status quo. Methods of the descriptive class characterise the technological sphere and present the latest scientific, technological and innovative achievements. The class of matrixes is formed by 3 methods combining intuitive and analytical element. They are used for analysing the future states of the researched systems on the basis of the identified mutual interactions between variables (forces, trends, events) occurring in the studied systems. Methods of the trend analyses family allow for the analysis of trends and potential factors that could affect the development of technology. Whereas the expert opinion class creates methods involving the collection and analysis of the views of a wide range of stakeholders engaged in the research, experts in the field. Methods of the creative approach class are characterized by freedom, flexibility and spontaneity in understanding of the studied phenomena. The smallest class is represented by statistical analyses and monitoring and intelligence. Methods belonging to the first-class determine correlation, probability and consequences of the event. On the other hand, the methods of another class take into account, inter alia, scanning of both the environment and technology, and include the identification of opportunities and risks associated with a given technology.

According to the author, F. Scapolo and A. L. Porter's classification does not cover all the possible and necessary tools for thorough technology analysis. The set of methods selected 
by F. Scapolo A. L. Porter lack above all the tools enabling identification, assessment of the factors that influence the development of technology. There are also no tools to evaluate the state of technology, its technological maturity, and technological possibilities. In contrast, scenario methods constitute a large class. According to the author, methods identified by F. Scapolo and A. L. Porter are to a greater extent associated with the decision-making trend rather than technology. Given the foregoing, it is noted that it is necessary to develop a methodology for classification of FTA methods which takes into account complementation of the methods catalogue identified by F. Scapolo and A. L. Porter.

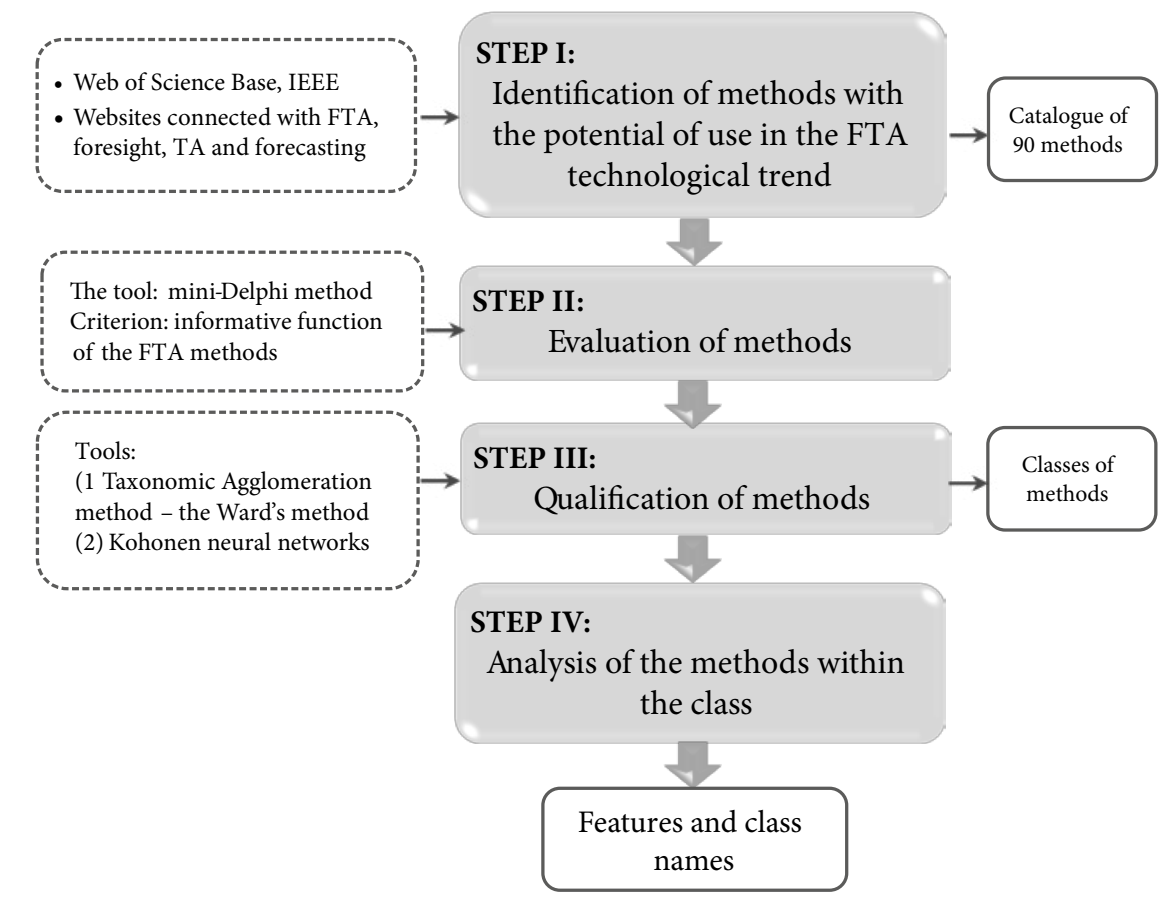

Fig. 1. Methodology for the classification of methods of future-oriented technology analysis

The detailed methodology of classification of methods of future-oriented technology analysis is shown in Figure 1. The research process was supported by the following research methods: critical analysis of literature, logical analysis and design, examination of the documents, mini-Delphi, statistical methods and artificial intelligence.

\section{Identification methods with potential use in the technological FTA current}

Given the definition and the function of FTA, the author has identified the methods used to evaluate technologies in technological forecasting, technological foresight, as well as in the future-oriented technology analysis based on literature review and direct observation. Subsequently, each of these methods has been examined in detail in terms of its use in the FTA technological stream. Table 2 shows the 90 finally selected methods. 
Table 2. Methods with potential use in the FTA technological stream

\begin{tabular}{|c|c|c|c|c|}
\hline $\begin{array}{l}\text { Name of the } \\
\text { method }\end{array}$ & $\begin{array}{l}\text { Name of the } \\
\text { method }\end{array}$ & $\begin{array}{l}\text { Name of the } \\
\text { method }\end{array}$ & $\begin{array}{c}\text { Name of the } \\
\text { method }\end{array}$ & $\begin{array}{c}\text { Name of the } \\
\text { method }\end{array}$ \\
\hline $\begin{array}{l}\text { factor analysis } \\
\text { (Georghiou } \\
\text { et al. } 2008 ; \\
\text { Magruk } 2011 \text {; } \\
\text { Saritas et al. 2014) }\end{array}$ & $\begin{array}{l}\text { source data } \\
\text { analysis } \\
\text { (Georghiou et al. } \\
\text { 2008; Magruk } \\
\text { 2011; Saritas et al. } \\
\text { 2014) }\end{array}$ & $\begin{array}{l}\text { analysis of long- } \\
\text { term (Cagnin } \\
\text { et al. 2008; } \\
\text { Georghiou et al. } \\
\text { 2008; Magruk } \\
\text { 2011; Saritas et al. } \\
\text { 2014) }\end{array}$ & $\begin{array}{l}\text { analysis of the } \\
\text { action (Cagnin } \\
\text { et al. 2008) }\end{array}$ & $\begin{array}{l}\text { institutional } \\
\text { analysis (Cagnin } \\
\text { et al. 2008; } \\
\text { Georghiou et al. } \\
\text { 2008; Magruk } \\
\text { 2011; Saritas et al. } \\
\text { 2014) }\end{array}$ \\
\hline $\begin{array}{l}\text { stakeholder } \\
\text { analysis (Cagnin } \\
\text { et al. 2008; } \\
\text { Georghiou et al. } \\
\text { 2008; Magruk } \\
\text { 2011; Saritas et al. } \\
\text { 2014) }\end{array}$ & $\begin{array}{l}\text { correspondence } \\
\text { analysis } \\
\text { (Georghiou et al. } \\
\text { 2008; Magruk } \\
\text { 2011; Saritas et al. } \\
\text { 2014) }\end{array}$ & $\begin{array}{l}\text { life cycle costing } \\
\text { (Gieraszewska, } \\
\text { Romanowska } \\
2014 \text { ) }\end{array}$ & $\begin{array}{l}\text { cost-benefit } \\
\text { analysis (Cagnin } \\
\text { et al. 2008; } \\
\text { Georghiou et al. } \\
\text { 2008; Magruk } \\
\text { 2011; Musango } \\
\text { 2012; Saritas et al. } \\
\text { 2014) }\end{array}$ & $\begin{array}{l}\text { life cycle analyses } \\
\text { S-curve analysis } \\
\text { (Georghiou et al. } \\
\text { 2008; Magruk } \\
\text { 2011; Musango } \\
\text { 2012; Saritas et al. } \\
\text { 2014) }\end{array}$ \\
\hline $\begin{array}{l}\text { megatrend } \\
\text { analysis } \\
\text { (Georghiou et al. } \\
\text { 2008; Magruk } \\
\text { 2011; Saritas et al. } \\
\text { 2014) }\end{array}$ & $\begin{array}{l}\text { morphological } \\
\text { analysis (Cagnin } \\
\text { et al. 2008; } \\
\text { Georghiou et al. } \\
\text { 2008; Magruk } \\
\text { 2011; Saritas et al. } \\
\text { 2014) }\end{array}$ & $\begin{array}{l}\text { patent analysis } \\
\text { (Georghiou et al. } \\
\text { 2008; Magruk } \\
\text { 2011; Saritas et al. } \\
\text { 2014) }\end{array}$ & $\begin{array}{l}\text { force field analysis } \\
\text { (Georghiou et al. } \\
\text { 2008; Magruk } \\
\text { 2011; Saritas et al. } \\
\text { 2014) }\end{array}$ & $\begin{array}{l}\text { benchmarking } \\
\text { (Georghiou et al. } \\
\text { 2008; Magruk } \\
\text { 2011; Saritas et al. } \\
\text { 2014) }\end{array}$ \\
\hline $\begin{array}{l}\text { requirements } \\
\text { analysis (Cagnin } \\
\text { et al. 2008) }\end{array}$ & $\begin{array}{l}\text { FMEA } \\
\text { (Georghiou et al. } \\
\text { 2008; Magruk } \\
\text { 2011; Saritas et al. } \\
\text { 2014) }\end{array}$ & $\begin{array}{l}\text { retrospective } \\
\text { analysis } \\
\text { (Georghiou et al. } \\
\text { 2008; Magruk } \\
\text { 2011; Saritas et al. } \\
\text { 2014) }\end{array}$ & $\begin{array}{l}\text { risk analysis } \\
\text { (Cagnin et al. } \\
\text { 2008; Georghiou } \\
\text { et al. 2008; } \\
\text { Magruk 2011; } \\
\text { Saritas et al. } \\
\text { 2014) }\end{array}$ & $\begin{array}{l}\text { scientometrics } \\
\text { (Georghiou et al. } \\
\text { 2008; Magruk } \\
\text { 2011; Saritas et al. } \\
\text { 2014) }\end{array}$ \\
\hline $\begin{array}{l}\text { cluster analysis } \\
\text { (Georghiou et al. } \\
\text { 2008; Magruk } \\
\text { 2011; Saritas et al. } \\
\text { 2014) }\end{array}$ & $\begin{array}{l}\text { STEEPVL } \\
\text { (Georghiou et al. } \\
\text { 2008; Magruk } \\
\text { 2011; Saritas et al. } \\
\text { 2014; Nazarko } \\
\text { et al. 2011) }\end{array}$ & $\begin{array}{l}\text { structural analysis } \\
\text { (Georghiou et al. } \\
\text { 2008; Magruk } \\
\text { 2011; Saritas et al. } \\
\text { 2014; Nazarko } \\
\text { et al. 2011) }\end{array}$ & $\begin{array}{l}\text { time series } \\
\text { analysis (Nazarko } \\
2004)\end{array}$ & $\begin{array}{l}\text { webometrics } \\
\text { (Georghiou et al. } \\
\text { 2008; Magruk } \\
\text { 2011; Saritas et al. } \\
\text { 2014) }\end{array}$ \\
\hline $\begin{array}{l}\text { trend and impact } \\
\text { analysis (Cagnin } \\
\text { et al. 2008) }\end{array}$ & $\begin{array}{l}\text { sensitivity analysis } \\
\text { (Georghiou et al. } \\
\text { 2008; Magruk } \\
\text { 2011; Saritas et al. } \\
\text { 2014) }\end{array}$ & $\begin{array}{l}\text { content analysis } \\
\text { (Georghiou et al. } \\
\text { 2008; Magruk } \\
\text { 2011; Saritas et al. } \\
\text { 2014) }\end{array}$ & $\begin{array}{l}\text { sustainability } \\
\text { analysis (Cagnin } \\
\text { et al. 2008; } \\
\text { Georghiou et al. } \\
\text { 2008; Magruk } \\
\text { 2011; Saritas et al. } \\
\text { 2014) }\end{array}$ & $\begin{array}{l}\text { ANKOT } \\
\text { (Georghiou et al. } \\
\text { 2008; Magruk } \\
\text { 2011; Saritas et al. } \\
\text { 2014) }\end{array}$ \\
\hline $\begin{array}{l}\text { desk research } \\
\text { (Georghiou et al. } \\
\text { 2008; Magruk } \\
\text { 2011; Saritas et al. } \\
\text { 2014) }\end{array}$ & $\begin{array}{l}\text { technology } \\
\text { barometer } \\
\text { (Georghiou et al. } \\
\text { 2008; Magruk } \\
\text { 2011; Saritas et al. } \\
\text { 2014) }\end{array}$ & $\begin{array}{l}\text { bibliometrics } \\
\text { (Cagnin et al. } \\
\text { 2008; Georghiou } \\
\text { et al. 2008; } \\
\text { Magruk 2011; } \\
\text { Saritas et al. 2014) }\end{array}$ & $\begin{array}{l}\text { brainstorming } \\
\text { (Georghiou et al. } \\
\text { 2008; Magruk } \\
\text { 2011; Saritas et al. } \\
\text { 2014) }\end{array}$ & $\begin{array}{l}\text { delphi (Cagnin } \\
\text { et al. 2008; } \\
\text { Georghiou et al. } \\
\text { 2008; Magruk } \\
\text { 2011; Saritas et al. } \\
\text { 2014) }\end{array}$ \\
\hline
\end{tabular}


Continue of Table 2

\begin{tabular}{|c|c|c|c|c|}
\hline $\begin{array}{l}\text { Name of the } \\
\text { method }\end{array}$ & $\begin{array}{c}\text { Name of the } \\
\text { method }\end{array}$ & $\begin{array}{c}\text { Name of the } \\
\text { method }\end{array}$ & $\begin{array}{l}\text { Name of the } \\
\text { method }\end{array}$ & $\begin{array}{l}\text { Name of the } \\
\text { method }\end{array}$ \\
\hline $\begin{array}{l}\text { classification trees } \\
\text { (Georghiou et al. } \\
\text { 2008; Magruk } \\
\text { 2011; Saritas et al. } \\
\text { 2014) }\end{array}$ & $\begin{array}{l}\text { trees references } \\
\text { (Cagnin et al. } \\
\text { 2008; Georghiou } \\
\text { et al. } 2008 ; \\
\text { Magruk } 2011 ; \\
\text { Saritas et al. } 2014 \text { ) }\end{array}$ & $\begin{array}{l}\text { probability trees } \\
\text { (Georghiou et al. } \\
\text { 2008; Magruk } \\
\text { 2011; Saritas et al. } \\
\text { 2014) }\end{array}$ & $\begin{array}{l}\text { diffusion of } \\
\text { technology } \\
\text { (Cagnin et al. } \\
\text { 2008) }\end{array}$ & $\begin{array}{l}\text { net present value } \\
\text { (Gieraszewska, } \\
\text { Romanowska } \\
\text { 2014) }\end{array}$ \\
\hline $\begin{array}{l}\text { wild cards } \\
\text { (Georghiou et al. } \\
\text { 2008; Magruk } \\
\text { 2011; Saritas et al. } \\
\text { 2014) }\end{array}$ & $\begin{array}{l}\text { trend } \\
\text { extrapolation } \\
\text { (Georghiou et al. } \\
\text { 2008; Magruk } \\
\text { 2011; Musango } \\
\text { 2012; Saritas et al. } \\
\text { 2014) }\end{array}$ & $\begin{array}{l}\text { production } \\
\text { function } \\
\text { (Gieraszewska, } \\
\text { Romanowska } \\
2014 \text { ) }\end{array}$ & $\begin{array}{l}\text { key technologies } \\
\text { (Georghiou et al. } \\
\text { 2008; Magruk } \\
\text { 2011; Saritas et al. } \\
\text { 2014) }\end{array}$ & $\begin{array}{l}\text { circle the future } \\
\text { (Cagnin et al. } \\
\text { 2008; Georghiou } \\
\text { et al. 2008; } \\
\text { Magruk 2011; } \\
\text { Saritas et al. 2014) }\end{array}$ \\
\hline $\begin{array}{l}\text { correlations } \\
\text { (Cagnin et al. } \\
\text { 2008; Musango } \\
\text { 2012) }\end{array}$ & $\begin{array}{l}\text { cross-impact } \\
\text { analysis (Cagnin } \\
\text { et al. 2008; } \\
\text { Georghiou et al. } \\
\text { 2008; Magruk } \\
\text { 2011; Saritas et al. } \\
\text { 2014) }\end{array}$ & $\begin{array}{l}\text { ranking lists } \\
\text { (prioritisation) } \\
\text { (Georghiou et al. } \\
\text { 2008; Magruk } \\
\text { 2011; Saritas et al. } \\
\text { 2014) }\end{array}$ & $\begin{array}{l}\text { macrohistory } \\
\text { (Georghiou et al. } \\
\text { 2008; Magruk } \\
\text { 2011; Saritas et al. } \\
\text { 2014) }\end{array}$ & $\begin{array}{l}\text { MANOA } \\
\text { (Georghiou et al. } \\
\text { 2008; Magruk } \\
\text { 2011; Saritas et al. } \\
\text { 2014) }\end{array}$ \\
\hline $\begin{array}{l}\text { technology } \\
\text { mapping (Cagnin } \\
\text { et al. 2008; } \\
\text { Gudanowska } \\
\text { 2014) }\end{array}$ & $\begin{array}{l}\text { technology } \\
\text { roadmapping } \\
\text { (Cagnin et al. } \\
\text { 2008; Nazarko } \\
\text { et al. 2011) }\end{array}$ & $\begin{array}{l}\text { Data Envelopment } \\
\text { Analysis (Cagnin } \\
\text { et al. 2008; } \\
\text { Georghiou et al. } \\
\text { 2008; Magruk } \\
\text { 2011; Saritas et al. } \\
\text { 2014) }\end{array}$ & $\begin{array}{l}\text { strategic position } \\
\text { and action } \\
\text { evaluation } \\
\text { (Gieraszewska, } \\
\text { Romanowska } \\
\text { 2014) }\end{array}$ & $\begin{array}{l}\text { portfolio methods } \\
\text { (Gieraszewska, } \\
\text { Romanowska } \\
\text { 2014) }\end{array}$ \\
\hline $\begin{array}{l}\text { technology } \\
\text { readiness levels } \\
\text { (Nazarko et al. } \\
\text { 2011) }\end{array}$ & $\begin{array}{l}\text { agent-based } \\
\text { modeling (Cagnin } \\
\text { et al. 2008) }\end{array}$ & $\begin{array}{l}\text { modelling and } \\
\text { simulation } \\
\text { (Georghiou et al. } \\
\text { 2008; Magruk } \\
\text { 2011; Saritas et al. } \\
\text { 2014) }\end{array}$ & $\begin{array}{l}\text { robust portfolio } \\
\text { modeling } \\
\text { (Georghiou et al. } \\
\text { 2008; Magruk } \\
\text { 2011; Saritas et al. } \\
\text { 2014) }\end{array}$ & $\begin{array}{l}\text { input-output } \\
\text { modeling (Cagnin } \\
\text { et al. 2008; } \\
\text { Georghiou et al. } \\
\text { 2008; Magruk } \\
\text { 2011; Saritas et al. } \\
\text { 2014) }\end{array}$ \\
\hline $\begin{array}{l}\text { design thinking } \\
\text { (Saritas et al. } \\
\text { 2014) }\end{array}$ & $\begin{array}{l}\text { technological } \\
\text { observation } \\
\text { (Cagnin et al. } \\
\text { 2008) }\end{array}$ & $\begin{array}{l}\text { life cycle } \\
\text { assessment } \\
\text { (Gieraszewska, } \\
\text { Romanowska } \\
2014 \text { ) }\end{array}$ & $\begin{array}{l}\text { assessment of the } \\
\text { impact on society } \\
\text { (Musango 2012) }\end{array}$ & $\begin{array}{l}\text { expert panel } \\
\text { (Georghiou et al. } \\
\text { 2008; Magruk } \\
\text { 2011; Saritas et al. } \\
\text { 2014) }\end{array}$ \\
\hline $\begin{array}{l}\text { analytic hierarchy } \\
\text { process (Cagnin } \\
\text { et al. 2008; } \\
\text { Georghiou et al. } \\
\text { 2008; Magruk } \\
\text { 2011; Musango } \\
\text { 2012; Saritas et al. } \\
\text { 2014) }\end{array}$ & $\begin{array}{l}\text { analog forecasting } \\
\text { (Cagnin et al. } \\
\text { 2008; Georghiou } \\
\text { et al. 2008; } \\
\text { Magruk 2011; } \\
\text { Saritas et al. 2014) }\end{array}$ & $\begin{array}{l}\text { stochastic } \\
\text { forecasting } \\
\text { (Georghiou et al. } \\
\text { 2008; Magruk } \\
\text { 2011; Saritas et al. } \\
\text { 2014) }\end{array}$ & $\begin{array}{l}\text { backcasting } \\
\text { (Georghiou et al. } \\
\text { 2008; Magruk } \\
\text { 2011; Saritas et al. } \\
\text { 2014) }\end{array}$ & $\begin{array}{l}\text { simple multi- } \\
\text { attribute ranking } \\
\text { technique } \\
\text { (Georghiou et al. } \\
\text { 2008; Magruk } \\
\text { 2011; Saritas et al. } \\
\text { 2014) }\end{array}$ \\
\hline
\end{tabular}


End of Table 2

\begin{tabular}{|c|c|c|c|c|}
\hline $\begin{array}{c}\text { Name of the } \\
\text { method }\end{array}$ & $\begin{array}{l}\text { Name of the } \\
\text { method }\end{array}$ & $\begin{array}{c}\text { Name of the } \\
\text { method }\end{array}$ & $\begin{array}{c}\text { Name of the } \\
\text { method }\end{array}$ & $\begin{array}{l}\text { Name of the } \\
\text { method }\end{array}$ \\
\hline $\begin{array}{l}\text { literature review } \\
\text { (Cagnin et al. } \\
\text { 2008; Georghiou } \\
\text { et al. 2008; } \\
\text { Magruk 2011; } \\
\text { Saritas et al. 2014) }\end{array}$ & $\begin{array}{l}\text { scenarios (Cagnin } \\
\text { et al. 2008; } \\
\text { Georghiou et al. } \\
\text { 2008; Magruk } \\
\text { 2011; Saritas et al. } \\
\text { 2014) }\end{array}$ & $\begin{array}{l}\text { social networks } \\
\text { analysis } \\
\text { (Georghiou et al. } \\
\text { 2008; Magruk } \\
\text { 2011; Saritas et al. } \\
\text { 2014) }\end{array}$ & $\begin{array}{l}\text { environmental } \\
\text { scanning } \\
\text { (Georghiou et al. } \\
\text { 2008; Magruk } \\
\text { 2011; Saritas et al. } \\
\text { 2014) }\end{array}$ & $\begin{array}{l}\text { technological } \\
\text { scanning } \\
\text { (Georghiou et al. } \\
\text { 2008; Magruk } \\
\text { 2011; Saritas et al. } \\
\text { 2014) }\end{array}$ \\
\hline $\begin{array}{l}\text { weak signals } \\
\text { (Cagnin et al. } \\
\text { 2008; Georghiou } \\
\text { et al. 2008; } \\
\text { Magruk 2011; } \\
\text { Saritas et al. 2014) }\end{array}$ & $\begin{array}{l}\text { survey (Cagnin } \\
\text { et al. 2008; } \\
\text { Georghiou et al. } \\
\text { 2008; Magruk } \\
\text { 2011; Saritas et al. } \\
\text { 2014) }\end{array}$ & $\begin{array}{l}\text { State of the Future } \\
\text { Index (Cagnin } \\
\text { et al. 2008; } \\
\text { Georghiou et al. } \\
\text { 2008; Magruk } \\
\text { 2011; Saritas et al. } \\
\text { 2014) }\end{array}$ & $\begin{array}{l}\text { SWOT (Cagnin } \\
\text { et al. 2008; } \\
\text { Georghiou et al. } \\
\text { 2008; Magruk } \\
\text { 2011; Saritas et al. } \\
\text { 2014) }\end{array}$ & $\begin{array}{l}\text { (MPA) multi } \\
\text { perspective } \\
\text { approach (Cagnin } \\
\text { et al. 2008; } \\
\text { Georghiou et al. } \\
\text { 2008; Magruk } \\
\text { 2011; Saritas et al. } \\
\text { 2014) }\end{array}$ \\
\hline $\begin{array}{l}\text { tech mining } \\
\text { (Cagnin et al. } \\
\text { 2008; Georghiou } \\
\text { et al. 2008; } \\
\text { Magruk 2011; } \\
\text { Saritas et al. 2014) }\end{array}$ & $\begin{array}{l}\text { theory of } \\
\text { inventive problem } \\
\text { solving (Cagnin } \\
\text { et al. 2008; } \\
\text { Georghiou et al. } \\
\text { 2008; Magruk } \\
\text { 2011; Saritas et al. } \\
\text { 2014) }\end{array}$ & $\begin{array}{l}\text { causal layered } \\
\text { analysis } \\
\text { (Georghiou et al. } \\
\text { 2008; Magruk } \\
\text { 2011; Saritas et al. } \\
\text { 2014) }\end{array}$ & $\begin{array}{l}\text { future workshops } \\
\text { (Cagnin et al. } \\
\text { 2008; Georghiou } \\
\text { et al. 2008; } \\
\text { Magruk 2011; } \\
\text { Saritas et al. 2014) }\end{array}$ & $\begin{array}{l}\text { IRR - internal } \\
\text { rate of return } \\
\text { (Gieraszewska, } \\
\text { Romanowska } \\
2014)\end{array}$ \\
\hline $\begin{array}{l}\text { visions of the } \\
\text { future (Cagnin } \\
\text { et al. 2008) }\end{array}$ & $\begin{array}{l}\text { PI - profitability } \\
\text { index }\end{array}$ & $\begin{array}{l}\text { complex adaptive } \\
\text { systems (Cagnin } \\
\text { et al. } 2008)\end{array}$ & $\begin{array}{l}\text { focus group } \\
\text { (Cagnin et al. } \\
2008 \text { ) }\end{array}$ & $\begin{array}{l}\text { technology } \\
\text { scouting } \\
\text { (Georghiou et al. } \\
\text { 2008; Magruk } \\
\text { 2011; Saritas et al. } \\
\text { 2014) }\end{array}$ \\
\hline
\end{tabular}

Source: own elaboration.

The set of methods that can be used for the future-oriented technology analysis continues to be extensive. Therefore, it seems essential to find ways to facilitate and systematize the process of selection of research methods with potential use in FTA. Given the various functions performed during the process of FTA, it is necessary to evaluate and organize these methods in terms of their use for the implementation (realization) of the following functions: (1) collecting information on the purpose and scope of the analysis; (2) collecting and collating information on technologies; (3) processing information about the past of the technologies; (4) processing and generating new information on the current state of technology; (5) gathering information on the impact of the environment on technology and technology on the environment; (6) transmission of the acquired information; (7) collecting information on the factors affecting the development of technology; (8) generating new information concerning the development of a particular technology; (9) interpreting and using the obtained information.

Methods with potential use in FTA have been evaluated, due to their informative function, by a group of experts. The mini-Delphi method was used for the evaluation of the 
methods. This method usually consists of a preparatory stage, the measurement of variables with the use of a questionnaire in two or more rounds, the analysis and implementation of the results after the completion of the study. The mini-Delphi method may take the form of direct talks, interviews, meetings or seminars, as well as interactions with experts via the Internet (Nazarko 2013). In this study, the experts were contacted by means of electronic communication. The research process of the Delphic proceedings is shown in Figure 2.

The study involved 12 experts. The experts have been selected purposefully, taking into account their knowledge and experience in the field of future studies. Subsequently, the method assessment questionnaire has been prepared in electronic form. The questionnaire had the shape of a matrix with dimensions of $90 \times 9$, whose rows were the names of the methods with potential use in the future-oriented technology analysis and the columns represented the functions implemented in the process of FTA, (Fig. 3). In addition, the author has developed a set of abstracts - basic information about the methods with potential use in FTA.

Subsequently, the developed Delphi questionnaire, along with information about the methods was distributed among the experts. The experts had at their disposal a four-step assessment scale and determined the extent to which a particular method performs the FTA function, where: 0 - unsuitability of a method for the realization of the FTA function;

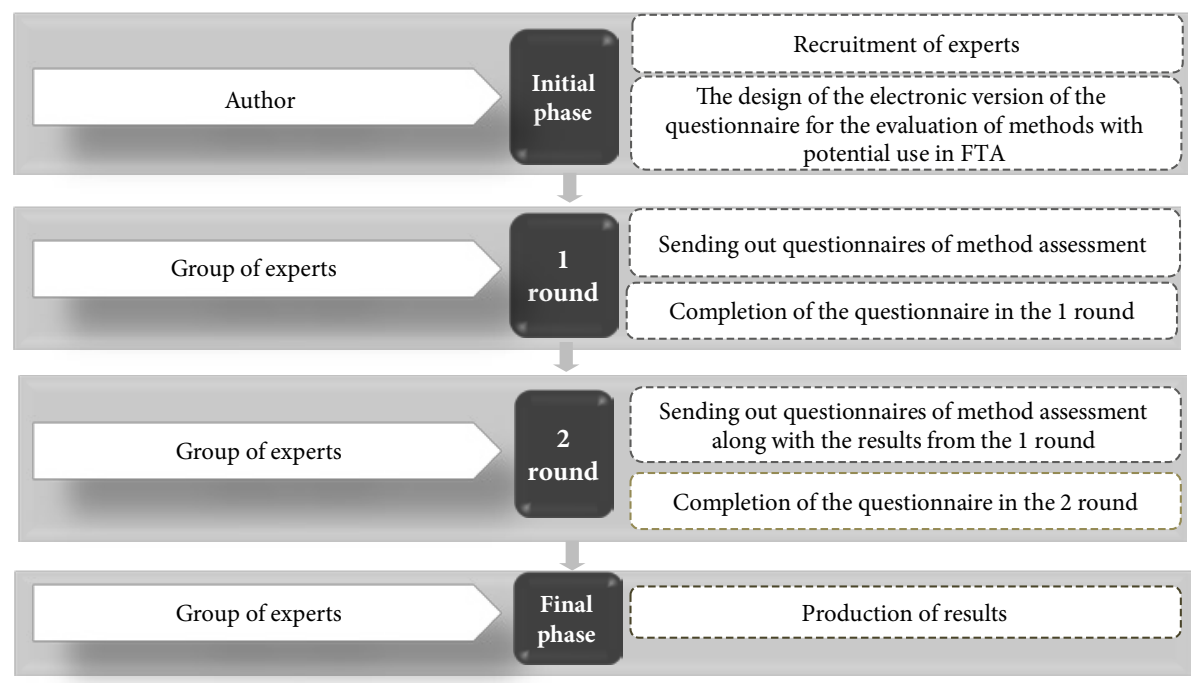

Fig. 2. Research process using the mini-Delphi method

\begin{tabular}{|l|l|l|l|l|l|}
\hline & Function 1 & Function 2 & Function 3 & Function 9 \\
\hline Method 1 & & & & \\
\hline Method 2 & & & \\
\hline Method 3 & & & \\
\hline$\ldots$ & & & \\
\hline Method 90 & & & \\
\hline
\end{tabular}

Fig. 3. Scheme of the questionnaire for the assessment of methods with the potential use in FTA 
1 - low applicability of the method for the realization of the FTA function; 2 - average applicability of the method for the realization of the FTA function; 3 - high applicability of the method for the realization of the FTA function.

The collected results were analysed in detail. Subsequently, the questionnaire for the evaluation of methods with potential use in FTA, together with the developed results from round 1 , was again sent to the same experts. In the next round of the study, the experts completed the same questionnaire, while having the opportunity to familiarize themselves with the aggregated results from the first round of the study. They were able to compare their own positions with the opinion of the group, and - after analysing the arguments could change their mind. The questionnaires received from the second round of the study have been re-examined. Eventually, a matrix of the implementation (realization) of the function of the FTA process through various methods has been obtained. To develop the final matrix, the dominant of the expert assessments has been adopted. Subsequently, with the use of the statistical methods and Kohonen artificial neural networks, these methods have been classified.

\section{Results of the classification of methods}

The process of classification of methods was carried out in two steps, both the statistical methods (cluster analysis method), and the methods of artificial intelligence (Kohonen networks) were used. For the determination of the number of classes the Ward's method of agglomeration with Euclidean distances is used, the result of which is a dendodram (diagram of clusters). The number of method clusters with the potential use in FTA was determined on the basis of the analysis of the chart of the course of agglomeration, as well as dendodram analysis. The chart of the course of agglomeration shows distances between clusters at the time of their bonding and its analysis makes it possible to find the intersections of the tree diagram and thus determine the number of classes (Fig. 4).

When analysing Figure 4 it can be seen that the first clear increase (leap) in agglomeration distance occurs at the level of about 320. It is a place, where multiple clusters formed at the same bonding distance (Jarocka 2015). This distance has been marked on the chart (Fig. 5) of the Ward's method. The point of intersection of the tree diagram determines the number of classes.

When analysing Figure 5 it was observed that 7 clusters can be identified. The methods of forming these classes were analysed and it was found that they do not always form substantially coherent classes. Therefore, to determine the methods in particular classes, because of the excellent classification abilities, artificial neural networks - Kohonen networks were used (Jamroz, Niedoba 2015).

An important advantage of neural networks is the fact that they allow the presentation of non-linearities and to resolve problems, for which it is difficult to precisely define the cause-and-effect relationships. They are effective in situations in which there are no simple rules for classification (Halicka 2011). According to R. Tadeusiewicz (Dudek-Dyduch et al. 2009), a Kohonen network can detect relationships that would be overlooked if the traditional statistical grouping method was used. Kohonen neural networks are non-model sys- 


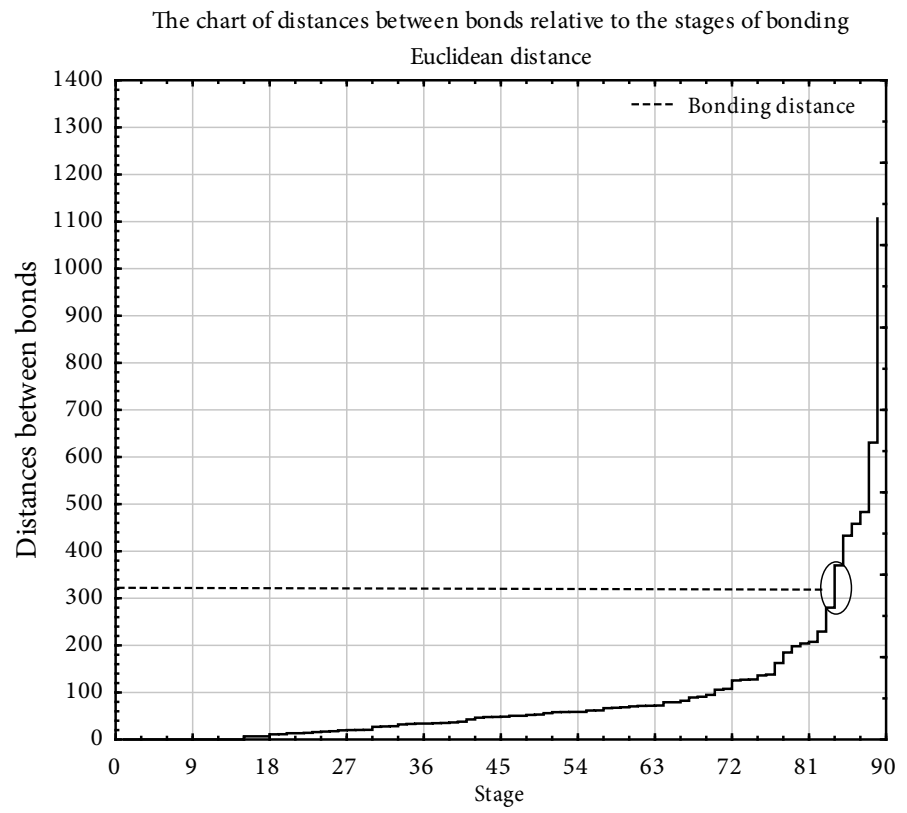

Fig. 4. Chart of the course of agglomeration

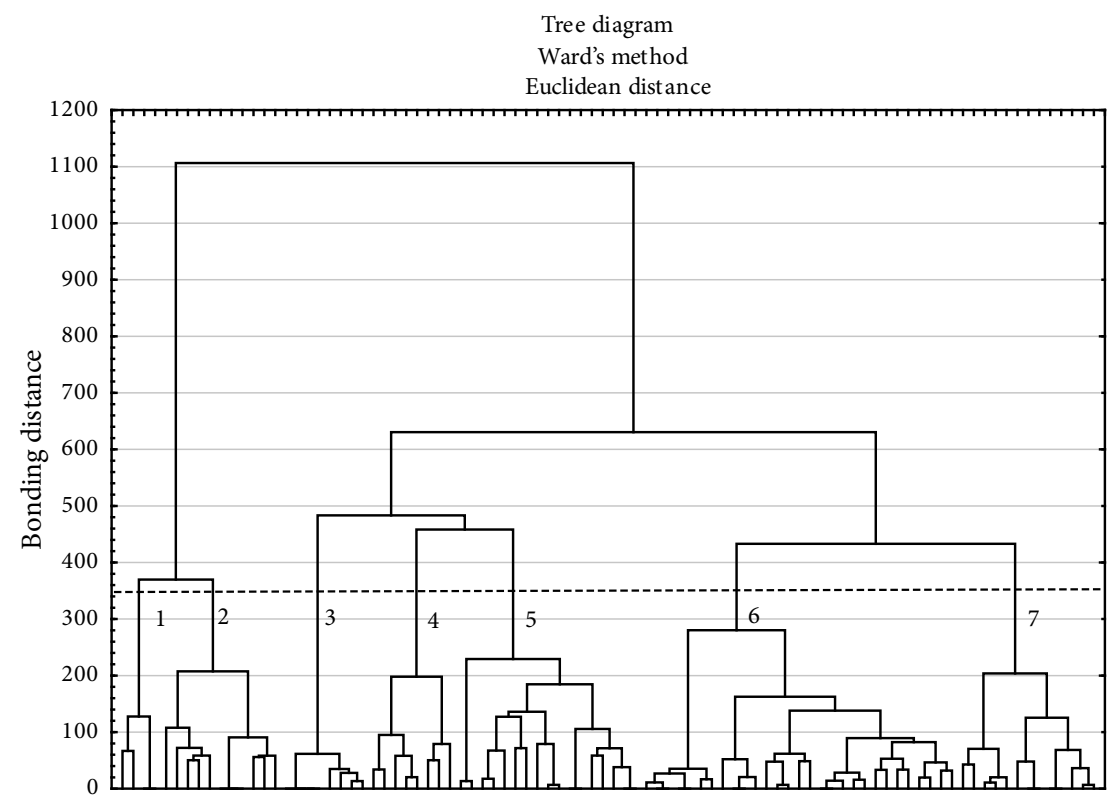

Fig. 5. Diagram of clusters of future oriented technology method

tems, they recognize the relationship between the studied individuals without any a priori assumptions as to their type, structure (Sulkava et al. 2015). This approach is different from statistical surveys, in which it is necessary to initially formulate a hypothesis, determine the research sample and select the methods of their verification (Mohebi, Bagirov 2015). 
In addition, neural networks are capable of identifying clusters with any spatial structure, are insensitive to the presence of non-standard units and are insensitive to the presence of a significant number of units not forming clusters (Sousa et al. 2015). Taking into account the mentioned advantages of the network and also taking into account the research problem, the Kohonen networks seem to be the right tool for the classification of methods with potential use in FTA.

The Kohenen network is referred to as the Self-Organizing Map (SOM), or Self-Organizing Feature Map (SOFM). The network aims to create such a structure, which would best replicate the interrelations between the input vectors. In the Kohonen network, individual neurons identify and recognize the individual clusters of data. Kohonen network has two layers: an input layer and an output layer (in the literature also known as competitive or Kohonen layer). The number of neurons in the input layer is unequivocal with the number of diagnostic features. In the undertaken research problem, the usefulness of the method for the implementation (realization) of a particular FTA function was adopted as a diagnostic feature, according to which the division of the methods was performed. During the study 9 functions were selected. In turn, the number of neurons in the output layer is determined by the number of homogeneous clusters. The analysis of the chart and diagram of the course of agglomeration made possible to identify 7 homogeneous clusters. Therefore, it was finally possible to construct a neural network consisting of 9 neurons in the input layer and 7 neurons in the output layer.

The developed Kohonen neural network has undergone learning and ultimately in the first class twelve methods were found, five methods in the second, and in subsequent classes, respectively: eight, eighteen, nine, twenty-two, and in the final cluster sixteen methods can be distinguished.

Afterwards, each of the classes was analysed in detail. The main characteristics of each of the classes were determined. Subsequently, authorial names for each of the classes were proposed. Detailed information on the classes, methods and the activation of each method are shown in Table 3.

First class, accumulation, consists of 12 methods primarily enabling the collection of information on technologies, based on literature databases, patent databases, reports, websites, radio and television. These methods also make it possible to: (1) organize, select data on the technology, its characteristics, determinants, possibilities of application, costs; (2) assess the state (advancement) of development works on new technologies; (3) acquire the knowledge and skills necessary to conduct research on technologies; (4) identify potential partners, competitors, suppliers and recipients of technology. As a result of these methods, collective knowledge bases concerning a particular technology are developed and presented in a synthetic manner, rankings and comparisons reflecting the interdependencies between several variables are generated.

Another class, creation, is complementary to the previous class. It consists of 5 methods for the accumulation of knowledge about technology, factors influencing its development, and the environment, based on expert knowledge. On the basis of knowledge, skills, and the experience of experts, new, often still undisseminated knowledge. Using the methods from this class, it is possible to: (1) estimate the probability, outcome, and time of the oc- 
Table 3. Authorial classes together with the FTA research methods belonging to them

\begin{tabular}{|c|c|c|}
\hline Class & $\begin{array}{c}\text { Main features of the } \\
\text { classes }\end{array}$ & Methods \\
\hline $\begin{array}{c}\text { I } \\
\text { accumulation } \\
12 \text { methods }\end{array}$ & $\begin{array}{l}\text { collection of } \\
\text { information }\end{array}$ & $\begin{array}{l}\text { source data analysis, patent analysis, webometrics, content } \\
\text { analysis, desk research, technology mapping, Technology } \\
\text { Readiness Levels TRL, literature review, technology } \\
\text { scouting, tech mining, scientometrics, bibliometrics }\end{array}$ \\
\hline $\begin{array}{c}\text { II } \\
\text { creation } \\
5 \text { methods }\end{array}$ & $\begin{array}{l}\text { generation of new } \\
\text { knowledge }\end{array}$ & $\begin{array}{l}\text { Delphi, key technologies, expert panel, Theory of } \\
\text { Inventive Problem Solving, focus group }\end{array}$ \\
\hline $\begin{array}{l}\text { III } \\
\text { retrospection } \\
8 \text { methods } \\
\end{array}$ & $\begin{array}{l}\text { analysis of historical } \\
\text { data in order to } \\
\text { identify trends }\end{array}$ & $\begin{array}{l}\text { analysis of long-term, life cycle analyses, S-curve analysis, } \\
\text { benchmarking, retrospective analysis, time series analysis, } \\
\text { ANKOT, trend extrapolation, macrohistory }\end{array}$ \\
\hline $\begin{array}{l}\text { IV } \\
\text { exploration } \\
18 \text { methods }\end{array}$ & $\begin{array}{l}\text { analysis of } \\
\text { technologies from } \\
\text { different perspectives: } \\
\text { social, technological, } \\
\text { economic, ecological, } \\
\text { political, values, legal }\end{array}$ & $\begin{array}{l}\text { force field analysis, FMEA, STEEPVL, structural analysis, } \\
\text { brainstorming, cross-impact analysis, strategic position } \\
\text { and action evaluation, portfolio methods, agent-based } \\
\text { modelling, modelling and simulation, input-output } \\
\text { modelling, assessment of the impact on society, survey, } \\
\text { SWOT, causal layered analysis, future workshops, social } \\
\text { networks analysis, environmental scanning }\end{array}$ \\
\hline $\begin{array}{l}\mathrm{V} \\
\text { quantification } \\
9 \text { methods }\end{array}$ & $\begin{array}{l}\text { an estimate of the } \\
\text { costs associated } \\
\text { to the lifecycle of } \\
\text { technologies }\end{array}$ & $\begin{array}{l}\text { life cycle costing, cost-benefit analysis, sensitivity analysis, } \\
\text { Net Present Value - NPV, production function, DEA, } \\
\text { life cycle assessment, internal rate of return, profitability } \\
\text { index }\end{array}$ \\
\hline $\begin{array}{c}\mathrm{VI} \\
\text { selection } \\
22 \text { methods }\end{array}$ & $\begin{array}{l}\text { identification, } \\
\text { classification, ranking } \\
\text { of analysed objects } \\
\text { (stimuli affecting } \\
\text { the development of } \\
\text { technology and the } \\
\text { analysed technologies) }\end{array}$ & $\begin{array}{l}\text { factor analysis, analysis of the action, institutional } \\
\text { analysis, correspondence analysis, risk analysis, cluster } \\
\text { analysis, sustainability analysis, classification trees, } \\
\text { probability trees, diffusion of technology, wild cards, } \\
\text { correlations, ranking lists, robust portfolio modelling, } \\
\text { analytic hierarchy process, stochastic forecasting, } \\
\text { simple multi-attribute ranking technique, weak signals, } \\
\text { technological observation, stakeholder analysis (citizen } \\
\text { panel), morphological analysis, technological scanning }\end{array}$ \\
\hline $\begin{array}{l}\text { VII } \\
\text { projection } \\
16 \text { methods }\end{array}$ & $\begin{array}{l}\text { presentation of the } \\
\text { development paths of } \\
\text { technologies; analysis } \\
\text { of trends and potential } \\
\text { events that may affect } \\
\text { the trajectory of } \\
\text { the development of } \\
\text { technologies }\end{array}$ & $\begin{array}{l}\text { requirements analysis, technology barometer, trees } \\
\text { references, circle the future (futures wheel), MANOA, } \\
\text { technology road mapping, design thinking, analogue } \\
\text { forecasting, backcasting, scenarios, estimating multi } \\
\text { perspective, visions of the future, complex adaptive } \\
\text { systems, megatrend analysis, trend and impact analysis, } \\
\text { state of the future index }\end{array}$ \\
\hline
\end{tabular}

Source: own elaboration.

currence of future events; (2) identify research directions that have the potential for development in the future; (3) determine the priority directions of technological development; (4) separate technologies, which to the highest degree contribute to the development of the examined area; (5) search for completely new solutions to complex problems related to the analysed technology; (6) develop new technological solutions.

The third class - retrospection - consists of 8 methods enabling the analysis of past events describing the causes and mechanisms of historical changes in order to understand 
the potential structure of the future. These methods allow for: (1) the analysis of the past in order to construct a better future; (2) identification and study of development trends in the economy, technology and society; (3) the examination of the market age of each product of a company or any technology used in it, and consequently to rationally plan the product portfolio and the costs associated with the introduction and creation of new products and technologies.

Fourth class - exploration - contains 18 methods for the examination of the environment and the analysis of the interior of the analysed object, and focusing on observation, testing, monitoring and systematic description of the technological, socio-cultural, ecological and economic context of the technology being tested. These methods allow for: (1) the analysis of external environmental factors (social, technological, economic, ecological, political, values, legal) affecting the development of the technology being tested; (2) predicting the probability of occurrence of future states of the analysed systems, based on the identified interactions between variables (forces, trends, events) occurring in the studied systems. Often, these methods make use of the group, creative work of a team.

Another class - quantification - consists of 9 methods for the identification and evaluation of all costs associated with the life cycle of technology. Using these methods makes it possible to: (1) compare the total expected costs with the total expected benefits of use, production of a given technology; (2) assess the effects that a given technology would have on the environment during its whole life; (3) determining the cost-effectiveness threshold of the use and production of a given technology at varying levels of force of factors affecting them.

The most numerous class - selection - consists of 22 methods for the identification, evaluation, classification and ranking of the examined objects. They can be used in the context of the key factors for influencing the future of a given technology, as well as in the context of the elements or components of technology. If during the FTA several technologies are analysed, the methods from this class will help in the assessment, ranking, and selection of technologies. These methods also make it possible to: (1) predict the occurrence of events affecting the innovative paths of development of the technology under assessment; (2) study the relationship between the factors influencing the development of technology; (3) make decisions in the context of significant, forward-looking technologies.

The last class - projection - includes methods for presenting the direct or indirect future of technology and the related changes and trends in selected areas. Using these methods makes it possible to: (1) shape the vision, formulate alternative scenarios for the development of a particular technology; (2) present technological development in the long term from various perspectives simultaneously: technical, organizational, social, environmental, economic, personal and others; detect, characterize and analyse important development trends (persisting for a long time) in the surveyed areas with a global reach, and their impact on the society. 


\section{Analysis of the results of research}

Analysing the resulting classes it can be seen that the collection, organization, and presentation of information related to the current state of the analysed technology will be possible with the use of the Class I methods (accumulation). For the processing of the acquired information on the current state of technology, as well as their presentation, the methods of retrospection are used (Class III). In contrast, to generate new information on the current state of technology and the cost of its application, Class V methods can be used (quantification). To collect information on the environment and factors affecting the development of technology, Class IV methods can be useful (exploration). The collection and generation of new information related to the future development of the analysed technology will be facilitated by Class VI tools (selection). In contrast, interpreting and using the acquired information on the development of the analysed technology will be enabled by the use of Class VII methods (projection). In turn, Class II methods (creation) are used for the performance of most of the FTA functions. The methods in this class are primarily useful in the generation of new information, but also are needed to gather information on a particular technology, its impact on the environment and the factors that determine the development of technology.

The proprietary classification presented in an article allowed to find common semantic ground for the methods belonging to a particular class. The new classification, given the rich methodical environment of the future-oriented technology analysis, also allows a more clear way to identify the characteristics of individual clusters that should be considered during the FTA design process and the formulation of the research methodology. The conducted study has allowed to reduce information overload and to establish the relationship between the studied methods.

It should be noted that the current division into classes is characterized by considerable freedom in the selection of methods, which can cause many ambiguities, especially for inexperienced researchers. In addition, the previous classification covers either only a few classes, referring to the important, but only general characteristics (over-simplifying the classification criteria, and thus the principle of selection of methods), or a small number of methods.

Some classification approaches (e.g. classification of foresight methods according to Popper (Georghiou et al. 2008), FTA classification (Cagnin et al. 2008), and classification of forecasting according to Porter (Roper et al. 2011)) are very popular in the literature on the subject, but in the opinion of the author, have their limitations. These classifications cover only a few dimensions.

Summing up the obtained results it should be stated that the undertaken subject is innovative in nature and its development will have practical application. It can become a source of helpful tips in the long-term process of technology management. The problem of the classification of methods used in the future-oriented technology analysis, undertaken in the article, constituted a considerable research challenge, both because of the attempt to approach the subject in an innovative way, an because of the existing - according to the author - conceptual and methodological chaos and insufficient theoretical basis in the literature on the subject and in practice concerning the classification of the future test methods. 
Novum in the research undertaken within the framework of the article should be considered in three areas: the identification of methods for the potential use in FTA (i), the selection of a criterion (ii), and the tools for the classification of these methods (iii). The author supplemented the set of methods applicable in the future-oriented technology analysis. In addition, she classified the methods in terms of their use in the implementation of individual FTA functions. So far, in the literature on the subject, the future-oriented technology analysis methods with regard to their usefulness in carrying out particular functions of this process have not been evaluated or organised. What is more, the process of classification of the future methods did not involve the artificial intelligence methods, which according to the author have a high potential for classification.

\section{Conclusions}

Currently - in an era characterized by significant dynamics of the environment - careful consideration, or even planning the future development of technology is gaining in importance. The tool allowing the presentation of a wide approach to the future of selected technologies, developed taking into account the knowledge and experience in that area is the future-oriented technology analysis. This process facilitates the integration of science and technology with business practice, and the identification of opportunities in the field of development of new technologies. It also allows the coordinated development of the technological potential along with the scenarios of market or sector development.

The lack of clear guidelines, both in Polish and foreign literature, limited the fully correct and effective use of the future-oriented technology analysis in the study of evolution of technology. The article presents the methods that can be used for future-oriented technology analysis. The text presents an original classification of the identified methods with potential use in FTA.

For the conducted future-oriented technology analysis to be fully fair, one should look at the research problem in a systemic way. According to the author, the ability to classify the FTA methods may support their complementary selection during the design of the predictive process, without limiting the flexibility of these studies at the same time.

The problem undertaken in the article is important, therefore, work in this area will be continued by the author. Further research will focus on the development of an algorithm, a method of joining and selecting methods from individual classes.

\section{References}

Alencar, M. S. M.; Porter, A. L.; Antunes, A. M. S. 2007. Nanopatenting patterns in relation to product life cycle, Technological Forecasting and Social Change 74(9): 1661-1680.

http://dx.doi.org/10.1016/j.techfore.2007.04.002

Amanatidou, E.; Butter, M.; Carabias, V.; Koennoelae, T.; Leis, M., Saritas, O.; Schaper-Rinkel, P.; van Rij, V. 2009. On concepts and methods in horizon scanning: lessons from initiating policy dialogues on emerging issues, Science and Public Policy 39(3): 279-291.

http://dx.doi.org/10.1016/j.futures.2010.11.006 
Andersen, P. D.; Alkærsig, L. 2014. Profile and trends in FTA approaches: a bibliometric analysis of special issues of international journals from four FTA, in 5th International Conference on FutureOriented Technology Analysis (FTA) - Engage Today to Shape Tomorrow, 27-28 November 2014, Brussels [online], [cited 24 September 2015]. Available from Internet: https://ec.europa.eu/jrc/sites/ default/files/fta2014-t3practice_151.pdf

Ayres, R. U. 1969. Technological forecasting and long-range planning. USA: McGraw-Hill.

Boden, M.; Johnston, R.; Scapolo, F. 2012. The role of FTA in responding to grand challenges: a new approach for STI policy, Science and Public Policy 39: 135-139. http://dx.doi.org/10.1093/scipol/scs026

Cagnin, C.; Havas A.; Saritas, O. 2013. Future-oriented technology analysis: its potential to address disruptive transformations, Technological Forecasting \& Social Change 80: 379-385. http://dx.doi.org/10.1016/j.techfore.2012.10.001

Cagnin, C.; Keenan, M.; Johnston, R.; Scapolo, F.; Barré, R. 2008. Future-oriented technology analysis. Strategic intelligence for an innovative economy. Springer-Verlag.

Cagnin, C.; Loveridge, D.; Saritas, O. 2011. FTA and equity: new approaches to governance, Futures 43: 279-291. http://dx.doi.org/10.1016/j.futures.2010.11.006

Cheng, A.-C.; Chen, C.-J.; Chen, C.-Y. 2008. A fuzzy multiple criteria comparison of technology forecasting methods for predicting the new materials development, Technological Forecasting and Social Change 75: 131-141. http://dx.doi.org/10.1016/j.techfore.2006.08.002

Cuhls, K. 2003. From forecasting to foresight processes - new participative foresight activities in Germany, Journal of Forecasting 22(2-3): 93-111. http://dx.doi.org/10.1002/for.848

Cunningham, S. W.; Kwakkel, J. 2011. Innovation forecasting: a case study of the management of engineering and technology literature, Technological Forecasting and Social Change 78: 346-357. http://dx.doi.org/10.1016/j.techfore.2010.11.001

Carabias-Huetter, V.; Haegeman, K. 2013. Future-oriented technology analysis to support decisionmaking in meeting global challenges, GAIA 22(1): 57-59.

Damrongchai, N.; Satangput, P.; Tegart, G.; Sripaipan, C. 2010. Future technology analysis for biosecurity and emerging infectious diseases in Asia-Pacific, Science and Public Policy 37: 50-61. http://dx.doi.org/10.1016/j.futures.2014.01.015

De Piante Henriksen, A. 1997. A technology assessment primer for management of technology, International Journal of Technology Management 13: 615-638.

Dudek-Dyduch, E.; Tadeusiewicz, R.; Horzyk, A. 2009. Neural network adaptation process effectiveness dependent of constant training data availability, Neurocomputing 72(13-15): 3138-3149. http://dx.doi.org/10.1016/j.neucom.2009.03.017

Eerola, A.; Miles, I. 2011. Methods and tools contributing to FTA: a knowledge-based perspective, Futures 43: 265-278. http://dx.doi.org/10.1016/j.futures.2010.11.005

Ejdys, J.; Ustinovicius, L.; Stankeviciene, J. 2015. Innovative application of contemporary management methods in a knowledge-based economy - interdisciplinarity in science, Journal of Business Economics and Management 16(1): 261-274. http://dx.doi.org/10.3846/16111699.2014.986192

Georghiou, L.; Harper, J. C.; Keenan, M.; Miles, I.; Popper, R. 2008. The handbook of technology foresight: concepts and practice. PRIME Series on Research and Innovation Policy. Cheltenham: Edward Elgar Publishing.

Georghiou, L.; Harper, J. C. 2013. Rising to the challenges - Reflections on future-oriented technology analysis, Technological Forecasting \& Social Change 80(3): 386-397.

http://dx.doi.org/10.1016/j.techfore.2012.10.009

Georghiou, L.; Harper, J. C.; Scapolo F. 2011. From priority-setting to societal challenges in futureoriented technology analysis, Futures 43: 229-231. http://dx.doi.org/10.1016/j.futures.2010.11.001 
Gesche, V. N.; Frese, J.; Koch, S.; Rongen, L.; Mela, P.; Jockenhoevel, S. 2012. Cell-based implants in heart surgery - opportunities and hurdles of this future oriented technology, Endoskopie Heute 25(3): 271-275. http://dx.doi.org/10.1055/s-0032-1325593

Gierszewska, G.; Romanowska, M. 2014. Analiza strategiczna przedsiębiorstwa [Strategic analysis of the company]. Warszawa: Polskie Wydawnictwo Ekonomiczne.

Gudanowska, A. E. 2014a. Technology mapping as a tool for technology analysis in foresight studies, in Technology Management Conference: ITMC 2014: IEEE International, 2014 Chicago, 1-4. http://dx.doi.org/10.1109/ITMC.2014.6918613

Gudanowska, A. E. 2013. Technology mapping in foresight studies as a tool of technology management. Polish experience, Contemporary Management Quarterly 12(4): 61-72.

Gudanowska, A. E. 2014b. Mapowanie technologii jako jedna z metod analizy technologii w świetle wybranych zagranicznych doświadczeń [Technology mapping as a method of technology analysis in the light of selected foreign experiences], Ekonomia i Zarzadzanie [Economics and Management] 6(1): 265-281. http://dx.doi.org/10.12846/j.em.2014.01.16

Guo, Y.; Xu, C.; Huang, L.; Porter, A. L. 2012. Empirically informing a technology delivery system model for an emerging technology: Illustrated for dye-sensitized solar cells, $R \& D$ Management 42(2): 133-149. http://dx.doi.org/10.1111/j.1467-9310.2012.00674.x

Guo, Y.; Wang, X.; Zhu, D. 2011. Innovation risk-utility pathway method applied to Dye-sensitized solar cells, Proceedings of the 2011 IEEE International Conference on Industrial Engineering and Engineering Management (IEEM), 6-9 December 2011, Singapore, 1305-1308.

http://dx.doi.org/10.1109/IEEM.2011.6118127

Haegeman, H.; Marinelli, E.; Scapolo, F.; Ricci, A.; Sokolov, A. 2013. Quantitative and qualitative approaches in Future-oriented Technology Analysis (FTA): From combination to integration?, Technological Forecasting \& Social Change 80(2): 386-397. http://dx.doi.org/10.1016/j.techfore.2012.10.002

Halicka, K.; Lombardi, P. A.; Styczynski, Z. 2015. Future-oriented analysis of battery technologies, in Industrial Technology (ICIT) 2015 IEEE International Conference, 17-19 March 2015, Seville, 1019-1024. http://dx.doi.org/10.1109/ICIT.2015.7125231

Halicka, K. 2015. Technology roadmapping in the management of renewable energy technologies, Trends Economics and Management IX(22): 19-25.

Halicka, K. 2014. Designing routes of development of renewable energy technologies, Procedia - Social and Behavioral Sciences 156: 58-62. http://dx.doi.org/10.1016/j.sbspro.2014.11.119 10

Halicka, K. 2011. Evaluation of distribution corporation profitability with application of artificial neural networks, Rynek Energii 1: 54-59.

Hamarat, C.; Kwakkel, J. H.; Pruyt, E. 2013. Adaptive Robust Design under deep uncertainty, Technological Forecasting \& Social Change 80(1): 7-18. http://dx.doi.org/10.1016/j.techfore.2012.10.004

Huang, L.; Guo, Y.; Peng, Z. C.; Porter, A. L. 2011. Characterising a technology development at the stage of early emerging applications: nanomaterial-enhanced biosensors, Technology Analysis \& Strategic Management 23(5): 527-544. http://dx.doi.org/10.1080/09537325.2011.565666

Huang, L.; Guo, Y.; Porter, A. L.; Youtie, J.; Robinson, D. K. R. 2012a. Visualising potential innovation pathways in a workshop setting: the case of nano-enabled biosensors, Technology Analysis \& Strategic Management 24(5): 527-542. http://dx.doi.org/10.1080/09537325.2012.674673

Huang, L.; Guo, Y.; Youties, J.; Porter, A. L. 2012b. Early commercialization pattern profiling: nanoenhanced biosensors, Proceedings - Technology Management for Emerging Technologies, 29 July - 2 August 2012, Vancouver, BC, 2612-2624.

Idier, D. 2000. Science fiction and technology scenarios: comparing Asimov's robots and Gibson's cyberspace, Technology in Society 22: 255-272. http://dx.doi.org/10.1016/S0160-791X(00)00004-X 
Jamroz, D.; Niedoba, T. 2015. Application of multidimensional data visualization by means of SelfOrganizing Kohonen Maps to evaluate classification possibilities of various coal types, Archives of Mining Sciences 60(1): 39-50. http://dx.doi.org/10.1515/amsc-2015-0003

Jarocka, M. 2015. Wybór formuły normalizacyjnej w analizie porównawczej obiektów wielocechowych [The choice of a formula of the data normalization in the comparative analysis of multivariate objects], Ekonomia i Zarzadzanie [Economics and Management] 1(7): 113-126. http://dx.doi.org/ 10.12846/j.em.2015.01.08

Kim, S. Y.; Lee, J. W.; Lee, O. S.; Ahn, E. Y.; Park, B. W.; Hwang, K. H. 2010. technology strategy and roadmap for geo-resource development in Korea, Smart Science for Exploration and Mining, 1-2: 985-987.

Kwakkel, J. H.; Pruyt, E. 2013. Exploratory modeling and analysis, an approach for model-based foresight under deep uncertainty, Technological Forecasting and Social Change 80(3): 419-431. http://dx.doi.org/10.1016/j.techfore

Loveridge, D.; Saritas, O. 2012. Ignorance and uncertainty: influences on future-oriented technology analysis, Technology Analysis \& Strategic Management 24(1): 57-59. http://dx.doi.org/10.1080/09537325.2012.715477

Ma, J.; Porter, A. L.; Aminabhavi, T. M. 2014. Identifying potential opportunities for emerging technologies by using literature linkages, in 5th International Conference on Future-Oriented Technology Analysis (FTA) - Engage Today to Shape Tomorrow, 27-28 November 2014, Brussels [online], [cited 24 September 2015]. Available from Internet: https://ec.europa.eu/jrc/sites/default/files/fta2014 presentation_t3s_129_jingma.pdf

Magruk, A. 2015. The most important aspects of uncertainty in the internet of things field - context of smart buildings, Procedia Engineering 122: 220-227. http://dx.doi.org/10.1016/j.proeng.2015.10.028

Magruk, A. 2011. Innovative classification of technology foresight methods, Technological and Economic Development of Economy 17(4): 700-716. http://dx.doi.org/10.3846/20294913.2011.649912

Marinho, S. V.; Cagnin, C. 2014. The roles of FTA in improving performance measurement systems to enable alignment between business strategy and operations: insights from three practical cases, Futures 59: 50-61. http://dx.doi.org/10.1016/j.futures.2014.01.015

Makridakis, S.; Wheelwright, S. C. 1978. Forecasting methods and applications. New York: Wiley.

Marinelli, E.; Miller, R.; Warnke, P. 2014. Future-oriented technology analysis: practice in search of theory?, Futures 59(9): 1661-1680. http://dx.doi.org/10.1016/j.futures.2014.01.011

Markus, M. L.; Mentzer, K. 2014. Foresight for a responsible future with ICT, Information Systems Frontiers 16(3): 353-368. http://dx.doi.org/10.1007/s10796-013-9479-9

Martin, B. 2001. Technology foresight in a rapidly globalizing economy, presentation from the International Conference on 'Technology Foresight for Central and Eastern Europe and the Newly Independent States', 4-5 April 2001, Vienna, Austria.

May, G. H. 1996. The future is ours: foreseeing, managing and creating the future. Westport, London: Praeger, Adamantine.

Mazurkiewicz, A.; Belina, B.; Poteralska, B.; Giesko, T.; Karsznia, W. 2015. Universal methodology for the innovative technologies assessment, Proceedings of the 10th European Conference on Innovation and Entrepreneurship, 17-18 September 2015, Genoa, 458-467.

Mikova, N.; Sokolova, A. 2014. Comparing information sources for identifying technology trends, in 5th International Conference on Future-Oriented Technology Analysis (FTA) - Engage Today to Shape Tomorrow, 27-28 November 2014, Brussels [online], [cited 24 September 2015]. Available from Internet: https://ec.europa.eu/jrc/sites/default/files/fta2014-t3practice_195.pdf

Mishra, S.; Deshmukh, S. G.; Vrat, P. 2002. Matching of technological forecasting technique to a technology, Technological Forecasting \& Social Change 69: 1-27.

http://dx.doi.org/10.1016/S0040-1625(01)00123-8 
Mohebi, E.; Bagirov, A. 2015. Modified self-organising maps with a new topology and initialisation algorithm, Journal of Experimental \& Theoretical Artificial Intelligence 27(3): 351-372. http://dx.doi.org/10.1080/0952813X.2014.954278

Moore, H. A.; Sanches, P.; Boman, M. 2014. Communities of vision, practice, and foresight, in 5th International Conference on Future-Oriented Technology Analysis (FTA) - Engage today to shape tomorrow, 27-28 November 2014, Brussels [online], [cited 24 September 2015]. Available from Internet: https://ec.europa.eu/jrc/sites/default/files/fta2014_presentation_t2practice_128_moore.pdf

Musango, J. K. 2012. Technology assessment of renewable energy sustainability in South Africa: Phd thesis. Stellenbosch University, Matieland [online], [cited 24 September 2015]. Available from Internet: http://ciret-transdisciplinarity.org/biblio/biblio_pdf/Josephine_Musango.pdf

Nazarko, J. (Ed.). 2004. Prognozowanie w zarządzaniu przedsiębiorstwem. Część II. Prognozowanie na podstawie szeregów czasowych [Forecasting in business management. Part II. Forecasting based on time series]. Białystok: Wydawnictwo Politechniki Białostockiej.

Nazarko, J. 2013. Regionalny foresight gospodarczy. Metodologia i instrumentarium badawcze [Regional economic foresight. Methodology and research instruments]. Warszawa: ZPWiM.

Nazarko, J. 2011. Kształtowanie polityki proinnowacyjnej regionu np. Foresightu technologicznego NT FOR Podlaskie 2020 [Creation of the Proinnovation Policy of a Region Based on Technological Foresight $<<$ NT FOR Podlaskie 2020 >>], Optimum - Studia Ekonomiczne 2(50): 241-251.

Nazarko, J. 1993. Modeling of electrical power distribution systems. Bialystok: Bialystok Technical University Publisher.

Nazarko, J.; Dębkowska, K.; Ejdys, J.; Glińska, E.; Halicka, K.; Kononiuk, A.; Olszewska, A.; Gudanowska, A.; Magruk, A.; Nazarko, Ł. 2011. Metodologia i procedury badawcze w projekcie Foresight Technologiczny NT for Podlaskie 2020: regionalna strategia rozwoju nanotechnologii [Methodology and research procedures in the NT Technology Foresight for the Podlaskie 2020 project: regional strategy for the development of nanotechnology]. Białystok: Oficyna Wydawnicza Politechniki Białostockiej.

Nazarko, J.; Ejdys, J.; Kononiuk, A.; Gudanowska, A.; Magruk, A.; Nazarko, Ł. 2012. Badanie ewaluacyjne projektów foresight realizowanych $w$ Polsce [Evaluation study of foresight projects implemented in Poland]. Warszawa: Ministerstwo Nauki i Szkolnictwa Wyższego.

Nygren, N. A.; Kontio, P.; Lyytimaki, J., Varho, V.; Tapio, P. 2015. Early adopters boosting the diffusion of sustainable small-scale energy solutions, Renewable \& Sustainable Energy Reviews 46: 79-87. http://dx.doi.org/10.1016/j.rser.2015.02.031

Robinson, D. K. R.; Huang, L.; Guo, Y.; Porter, A. L. 2013. Forecasting Innovation Pathways (FIP) for new and emerging science and technologies, Technological Forecasting \& Social Change 80(2): 267-285. http://dx.doi.org/10.1016/j.techfore.2011.06.004

Robinson, D. K. R.; Propp, T. 2008. Multi-path mapping for alignment strategies in emerging science and technologies, Technological Forecasting and Social Change 75(40): 517-538. http://dx.doi.org/10.1016/i.techfore.2008.02.002

Roper, A. T.; Cunningham, S. W.; Porter, A. L.; Mason, T. W.; Rossini, F. A.; Banks, J. 2011. Forecasting and management of technology. 2nd ed. Wiley.

Saritas, O.; Burmaoglu, S.; Tabak, A. 2014. The evolution of the use of foresight methods: a bibliometric analysis of global research output for cutting-edge FTA approaches, in 5th International Conference on Future-Oriented Technology Analysis (FTA) - Engage today to shape tomorrow, 27-28 November 2014, Brussels [online], [cited 24 September 2015]. Available from Internet: https://ec.europa.eu/ jrc/sites/default/files/fta2014-t3practice_185.pdf

Schaper-Rinkel, P. 2013. The role of future-oriented technology analysis in the governance of emerging technologies: The example of nanotechnology, Technological Forecasting \& Social Change 80: 444-452. http://dx.doi.org/10.1016/j.techfore.2012.10.007 
Shin, J.; Coh, B.; Lee, C. 2013. Robust future-oriented technology portfolios: Black-Litterman approach, $R$ \& D Management 43(2): 267-285. http://dx.doi.org/10.1111/radm.12022

Sousa, R. G.; Rocha Neto, A. R.; Cardoso, J. S.; Barreto, J. A. 2015. Robust classification with reject option using the self-organizing map, Neural Computing \& Applications 26(7): 1603-1619. http://dx.doi.org/10.1007/s00521-015-1822-2

Sulkava, M.; Sepponen, A. M.; Yli-Heikkila, M.; Latukka, A. 2015. Clustering of the self-organizing map reveals profiles of farm profitability and upscaling weights, Neurocomputing 147: 197-206. http://dx.doi.org/10.1016/j.neucom.2013.09.063

Tran, T. A.; Daim, T. 2008. A taxonomic review of methods and tools applied in technology assessment, Technological Forecasting and Social Change 75: 1396-1405.

http://dx.doi.org/10.1016/j.techfore.2008.04.004

Weber, M. K.; Harper, J. C.; Könnölä, T.; Barceló, V. C. 2012. Coping with a fast-changing world: towards new systems of future-oriented technology analysis, Science and Public Policy 39: 153-165. http://dx.doi.org/10.1093/scipol/scs012

UNIDO. 2005. UNIDO Technology foresight manual. Organizations and methods, Vol. 1. UNIDO, Vienna.

Vanston, J. H. 1995. Technology forecasting: an aid to effective technology management. Technology Futures, Inc., Austin, TX.

Katarzyna HALICKA. PhD, since 2008 is an assistant professor at the Faculty of Management and Finance at the Bialystok University of Technology. Deputy Head of the Department of Business Informatics and Logistics and an editor of the logistics management section of the Economics and Management Journal. Author of about 60 scientific articles. Research interests: forecasting, foresight studies, technology management, methods of artificial intelligence. 